\title{
PENERAPAN METODE MULTIPLE DISCRIMINANT ANALYSIS UNTUK MENGUKUR TINGKAT KESEHATAN YANG MENGINDIKASIKAN GEJALA FINANCIAL DISTRESS PADA BANK UMUM SYARIAH
}

\author{
Shofaun Nada*
}

\begin{abstract}
The Application of Multiple Discriminant Analysis Method (Mda) For Measuring Health Symptoms That Indicate Financial Distress In Islamic Banks (BUS). This research aims to account, analyse and compare the level of Islamic commercial bank's health using CAMELS method mentioned in PBI No.9/1/PBI/2007 and SEBI No 9/24/DPbS/2007 and using multiple discriminant analysis (MDA) altman z-score method. There are only four of six factors that used in CAMELS: capital, asset, earning and liquidity excluding Management and Sensitivity of Market Risk factor. The variables of capital factors are KPMM and ECR ratio. Asset factor consist of KAP and NPF ratio. Earning factor contains four ratios, such as NOM, ROA, ROE and REO.
\end{abstract}

Keywords: healthy bank, CAMELS, financial distress

Abstrak: Penerapan Metode Multiple Discriminant Analysis (MDA) untuk Mengukur Tingkat Kesehatan yang Mengindikasikan Gejala Financial Distress pada Bank Umum Syariah (BUS). Penelitian ini bermaksud menjelaskan, menganalisis, dan membandingkan tingkat kesehatan bank komersil syariah dengan menggunakan metode CAMELS sesuai dengan PBI No.9/1/PBI/2007 dan SEBI No 9/24/DPbS/2007 serta menggunakan analisis diskriminan altman metode z-score (MDA). Hanya ada empat dari enam faktor yang digunakan dalam metode CAMELS, yakni: capital, asset, earning, dan liquidity. Sedangkan manajemen dan sensitivitas faktor risiko pasar tidak termasuk di dalamnya. Adapun variabel faktor capital adalah rasio KPMM dan ECR. Faktor aset terdiri atas rasio KAP dan NPF. Faktor Produktif berisi empat rasio, seperti NOM, ROA, ROE, dan REO.

Kata Kunci: bank sehat, CAMELS, finansial distress

Naskah diterima: 5 Januari 2013, direvisi: 1 Juni 2013, disetujui: 13 Juni 2013.

* Himpunan Ilmuwan dan Sarjana Syariah Indonesia (HISSI). Jl. Ir. H. Juanda, Ciputat, Tangerang Selatan, Banten. E-mail: shofa.nada@gmail.com 


\section{Pendahuluan}

Eksistensi bank syariah saat ini kian popular. Antusiasme masyarakat terhadap lembaga keuangan yang terbilang baru dalam kancah perekonomian Indonesia ini semakin meningkat, termasuk di kalangan pebisnis. Sebagai lembaga keuangan yang memiliki wewenang melakukan banyak aktivitas, bank syariah dihadapkan pada pelbagai macam risiko inherent (melekat). Risiko yang mungkin terjadi dapat menimbulkan kerugian bagi bank jika tidak dideteksi dan dikelola sedini mungkin. Pelbagai eksposur risiko tersebut bisa berupa penurunan tingkat kesehatan bank hingga risiko kebangkrutan.

Salah satu contoh kasus mengenai risiko yang dihadapi perbankan adalah krisis moneter tahun 1997. Krisis moneter telah memporak-porandakan sendi-sendi perekonomian yang kemudian bertransformasi menjadi krisis ekonomi berkepanjangan yang memberikan efek negatif terhadap kinerja perekonomian Indonesia. Kondisi tersebut tercermin dari banyaknya sejumlah bank yang collapse karena dianggap tidak mampu lagi mempertahankan going concern-nya sehingga terpaksa

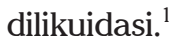

Oleh karena itu, untuk mengantisipasi agar kejadian di tahun 1997 tidak terulang kembali diperlukan suatu tindakan sedini mungkin untuk mengukur kondisi serta tingkat kesehatan bank. Metode penilaian untuk menilai kondisi kesehatan bank termasuk bank syariah sangat variatif. Salah satu metode yang juga merupakan aturan baku mengenai teknik penilaian kesehatan bank syariah adalah metode CAMELS. Teknik penilaian ini dikeluarkan oleh Bank Indonesia pada tanggal 24 Januari 2007 melalui Peraturan Bank Indonesia (PBI) No.9/1/DPbS/2007. Metode lain yang dapat digunakan ialah metode multiple discriminant analysis (MDA) yang dipelopori oleh Edward I. Altman. Teknik penilaian ini dilakukan untuk menilai eksistensi gejala financial distress (kesulitan keuangan) yang mengarah pada kebangkrutan.

Berdasarkan latar belakang di atas, maka permasalahan yang akan diangkat dalam studi ini adalah bagaimana tingkat kesehatan bank jika menggunakan metode CAMELS serta menggunakan metode MDA Altman Z-Score guna menilai eksistensi gejala financial distress pada bank umum syariah.

Ruang lingkup studi mengenai tingkat kesehatan bank umum syariah, dibatasi pada hal-hal sebagai berikut: Pertama, teknik analisis perhitungan rasio tingkat kesehatan bank menggunakan metode CAMELS hanya menggunakan empat dari enam unsur yang ada yaitu, capital, asset, earning dan liquidity. Faktor management dan sensitivity to market risk tidak diikutsertakan karena penelitian ini sepenuhnya

\footnotetext{
${ }^{1}$ Louisa Br Simanjuntak, Analisa Tingkat Kesehatan untuk Mengindikasi Gejala Financial Distress dengan Menggunakan Metode MultipleDiscriminant Analysis (MDA), (Jakarta: Fakultas Ekonomi Universitas Trisakti, 2003), h. 1.
} 
menggunakan data sekunder berupa laporan keuangan yang telah diaudit secara independen.

Kedua, objek penelitian ini adalah bank-bank syariah di Indonesia yang telah menjalankan kegiatan operasional minimal lima tahun. Dari sekian bank syariah yang ada di Indonesia, hanya tiga bank yang memenuhi kriteria, yakni: Bank Muamalat Indonesia (BMI), Bank Syariah Mandiri (BSM), dan Bank Mega Syariah (BMS).

Ketiga, aspek penelitian yang dikaji adalah pure (murni) hasil perhitungan kondisi kesehatan bank syariah (BMI, BSM, dan BMS) yang menggunakan unsur capital, assets, earning dan liquidity serta metode Multiple Discriminant Analysis (MDA) milik Altman. Penelitian ini tidak memasukan unsur eksternal berupa keadaan ekonomi negara, kebijakan pemerintah, inflasi, dan deflasi.

\section{Metodologi}

Metode penelitian yang digunakan dalam penelitian ini adalah kuantitatif. Objek penelitian adalah bank umum syariah yang telah beroperasi minimal lima tahun ya-itu, Bank Muamalat Indonesia, Bank Syariah Mandiri dan Bank Mega Syariah dengan kurun waktu empat tahun yaitu periode 2007-2010.

Jenis data dalam penelitian ini ialah data dokumenter berupa laporan keuangan tahunan yang telah diaudit secara independen. Sementara sumber data yang diperoleh berupa data sekunder yakni pelbagai laporan keuangan yang dikeluarkan oleh sejumlah lembaga yang berwenang, seperti Bank Indonesia dan bank-bank umum syariah yang menjadi target penelitian. Data-data laporan tersebut tersedia di situs resmi BI dan BUS yang menjadi objek penelitian.

Metode analisis data yang digunakan adalah teknik analisis rasio kesehatan CAMELS-yang dalam penelitian ini hanya digunakan faktor capital, assets, earnings, dan liquidit—serta metode multiple discriminant analysis (MDA) Altman Z-Score. Perhitungan faktor capital, assets, earnings, dan liquidity digunakan untuk menilai serta menganalisis tingkat kesehatan bank syariah yang menjadi objek penelitian. Pasca diketahui status atau kondisi tingkat kesehatan bank-bank syariah tersebut, maka tahap selanjutnya adalah menilai serta mengukur eksistensi gejala financial distress menggunakan metode MDA.

Multiple discriminant analysis (MDA) atau disebut juga dengan analisis diskriminan ganda. Pada dasarnya, analisis diskriminan merupakan suatu teknik analisis yang bertujuan untuk mengelompokkan atau memasukkan suatu objek ke dalam suatu grup. Perbedaan dengan analisis diskriminan biasa adalah terletak pada jum- 
lah grup. Jika pada analisis diskriminan hanya terdiri atas 1 atau 2 grup, pada analisis diskriminan ganda (MDA) jumlah grup lebih dari $2 .{ }^{2}$

Metode MDA yang digunakan pada penelitian ini merupakan metode yang dipopulerkan oleh Edward I. Altman untuk mengukur gejala financial distress yang terdiri atas lima variabel rasio dengan masing-masing koefisien pengalinya (multiplier coefficient). Setelah menghitung nilai dari masing-masing variabel yang terdiri atas variabel $\mathrm{X}_{1}$ sampai dengan $\mathrm{X}_{5}$ kemudian dikalikan dengan nnilai koefisien variabel masing-masing, maka akan didapatkan nilai $\mathrm{Z}$. Jika nilai $\mathrm{Z}<1.81$ maka perusahaan atau bank mengalami kesulitan keuangan dan risiko tinggi.untuk nilai $\mathrm{Z}$ antara 1.81 - 2.99, bank dianggap berada pada daerah abu-abu (grey area) dan jika nilai $Z$ dia atas 2,99 maka bank berada dalam keadaan yang sehat dan kemungkinan akan adanya kebangkrutan sangat kecil. ${ }^{3}$

Setelah diperoleh hasil berupa nilai Z pada setiap bank di setiap tahunnya, penulis mencoba membuat formula berupa persamaan fungsi diskriminan baru yang dibuat berdasarkan hasil penelitian menggunakan formula Altman. Proses ini dilakukan dengan memasukan semua hasil penelitian ke dalam program SPSS 20.0 untuk selanjutnya diolah menggunakan analisis diskriminan guna mencari persamaan baru. Hal ini bertujuan untuk membandingkan hasil penelitian yang menggunakan fungsi diskriminan milik Altman dengan fungsi diskriminan baru, di mana jumlah dan nilai pada masing-masing "d" diperoleh dari hasil perhitungan menggunakan formula Altman.

\section{Hasil Perhitungan Capital, Asset, Earning dan Liquidity}

Pada bagian ini penulis memuat tabel hasil perhitungan tingkat kesehatan bank syariah (BMI, BSM dan BMS) periode tahun 2007-2010 dengan menggunakan faktor capital, asset, earning dan liquidity. Tabel hasil perhitungan dari setiap komponen tersebut dimasukan dalam kertas kerja penetapan peringkat komponen.

Tabel 1 : Kertas Kerja Penetapan Peringkat Komponen

Bank Muamalat Indonesia (BMI) Tahun 2007-2010

\begin{tabular}{|c|c|c|c|}
\hline No & Komponen & Hasil Perhitungan & Peringkat \\
\hline
\end{tabular}

\footnotetext{
${ }^{2}$ Bilson Simamora, Analisis Multivariat Pemasaran, (Jakarta: PT. RajaGrafindo Persada, 2005), h. 143.

3 Endri, "Prediksi Kebangkrutan Bank Untuk Menghadapi dan Mengeloal Perubahan Lingkungan Bisnis: Analisis Model Altman's Z-Score”, Perbanas Quarterly Review, Volume 2, (Maret, 2009), h. 43.
} 


\begin{tabular}{|c|c|c|c|c|c|c|c|c|c|}
\hline & & & & & & 2007 & 2008 & 2009 & 2010 \\
\hline & Permodalan & & & & & & & & \\
\hline \multirow[t]{3}{*}{1} & a. KPMM & $10.70 \%$ & $11.49 \%$ & $10.94 \%$ & $12.80 \%$ & 2 & 2 & 2 & 1 \\
\hline & b. ECR & 3.81 & 2.54 & 1.7 & 2.72 & 2 & 3 & 4 & 3 \\
\hline & $\underline{\text { Kualitas Aset }}$ & & & & & & & & \\
\hline \multirow[t]{4}{*}{2} & a. KAP & 0.97 & 0.97 & 0.96 & 0.96 & 2 & 2 & 2 & 2 \\
\hline & b. NPF & $2.08 \%$ & $2.07 \%$ & $4.25 \%$ & $3.82 \%$ & 2 & 2 & 2 & 2 \\
\hline & Rentabilitas & & & & & & & & \\
\hline & a. NOM & $-0.47 \%$ & $-0.26 \%$ & $-0.56 \%$ & $-0.31 \%$ & 5 & 5 & 5 & 5 \\
\hline \multirow[t]{4}{*}{3} & b. ROA & $1.40 \%$ & $1.99 \%$ & $0.43 \%$ & $1.53 \%$ & 2 & 1 & 4 & 1 \\
\hline & c. REO & $91.61 \%$ & $82.00 \%$ & $93.47 \%$ & $87.07 \%$ & 5 & 2 & 5 & 4 \\
\hline & d. ROE & $13.03 \%$ & $18.59 \%$ & $4.50 \%$ & $15.33 \%$ & 2 & 2 & 4 & 2 \\
\hline & Likuiditas & & & & & & & & \\
\hline \multirow[t]{2}{*}{4} & a. STM & $0.63 \%$ & $0.59 \%$ & $20.33 \%$ & $14.42 \%$ & 5 & 5 & 2 & 4 \\
\hline & b. STMP & $8.27 \%$ & $5.91 \%$ & $26.64 \%$ & $20.61 \%$ & 5 & 5 & 4 & 4 \\
\hline
\end{tabular}

Sumber: Diolah dari laporan keuangan Bank Muamalat Indonesia

Berdasarkan data statistik atas, masing-masing rasio dari tiap komponen mengalami fluktuasi dan cenderung progres. Fakta menarik datang dari faktor kualitas aset. Selama empat tahun, dua komponen rasio faktor tersebut yaitu rasio KAP dan ECR senantiasa menduduki peringkat kedua. Meskipun beberapa rasio ada yang mengalami penurunan, namun secara keseluruhan Bank Muamalat Indonesia cukup mampu mempertahankan kondisi kesehatannya.

Tabel 2 : Kertas Kerja Penetapan Peringkat Komponen Bank Syariah Mandiri (BSM) Tahun 2007-2010

\begin{tabular}{|c|c|c|c|c|c|c|c|c|c|}
\hline \multirow{2}{*}{ No } & \multirow{2}{*}{ Komponen } & \multirow{2}{*}{\multicolumn{4}{|c|}{ Hasil Perhitungan }} & \multicolumn{4}{|c|}{ Peringkat } \\
\hline & & & & & & 2007 & 2008 & 2009 & 2010 \\
\hline \multirow{3}{*}{1} & $\underline{\text { Permodalan }}$ & & & & & & & & \\
\hline & a. KPMM & $9.20 \%$ & $6.93 \%$ & $7.61 \%$ & $5.74 \%$ & 2 & 4 & 4 & 5 \\
\hline & b. ECR & 1.06 & 1.86 & 1.96 & 2.27 & 4 & 4 & 4 & 3 \\
\hline \multirow{3}{*}{2} & Kualitas Aset & & & & & & & & \\
\hline & a. KAP & 0.94 & 0.97 & 0.97 & 0.98 & 3 & 2 & 2 & 2 \\
\hline & b. NPF & $4.35 \%$ & $5.64 \%$ & $4.68 \%$ & $3.44 \%$ & 2 & 3 & 2 & 2 \\
\hline \multirow{5}{*}{3} & Rentabilitas & & & & & & & & \\
\hline & a. NOM & $-0.32 \%$ & $-0.60 \%$ & $-0.41 \%$ & $-0.35 \%$ & 5 & 5 & 5 & 5 \\
\hline & b. ROA & $0.80 \%$ & $1.35 \%$ & $1.98 \%$ & $2.69 \%$ & 3 & 2 & 1 & 1 \\
\hline & c. REO & $106.21 \%$ & $101.48 \%$ & $93.06 \%$ & $91.96 \%$ & 5 & 5 & 5 & 5 \\
\hline & d. ROE & $8.19 \%$ & $13.93 \%$ & $20.63 \%$ & $29.68 \%$ & 3 & 2 & 1 & 1 \\
\hline 4 & Likuiditas & & & & & & & & \\
\hline
\end{tabular}




\begin{tabular}{lllllllll}
\hline a. STM & $0.29 \%$ & $0.00 \%$ & $0.30 \%$ & $0.00 \%$ & 5 & 5 & 5 & 5 \\
\hline b. STMP & $22.63 \%$ & $18.02 \%$ & $9.26 \%$ & $5.01 \%$ & 4 & 5 & 5 & 5 \\
\hline
\end{tabular}

Sumber: Diolah dari laporan keuangan Bank Syariah Mandiri

Kondisi yang serupa namun tak sama diperlihatkan oleh Bank Syariah Mandiri. Selama kurun waktu periode tahun 2007-2010, trend kesehatan bank jika dilihat per komponen rasio dari masing-masing faktor sangat variatif. Selain ada beberapa rasio yang berfluktuasi, tidak sedikit pula rasio yang bersifat konsisten, salah satunya ialah rasio REO dan STM. Hal menarik dari tabel di atas tak lain adalah nilai rasio KPMM pada Bank Syariah Mandiri yang kian merosot. Keadaan ini menjadi menarik lantaran Bank Syariah Mandiri merupakan bank syariah terbesar di Indonesia saat ini. Akan tetapi, bank ini justru kurang baik dalam mengatur serta mengelola komposisi permodalan hingga harus menempati peringkat kelima pada tahun 2010 dengan nilai rasio KPMM yang hanya sebesar 5.74\%.

Tabel 3 : Kertas Kerja Penetapan Peringkat Komponen Bank Mega Syariah (BMS)Tahun 2007-2010

\begin{tabular}{|c|c|c|c|c|c|c|c|c|c|}
\hline \multirow{2}{*}{ No } & \multirow{2}{*}{ Komponen } & \multirow{2}{*}{\multicolumn{4}{|c|}{ Hasil Perhitungan }} & \multicolumn{4}{|c|}{ Peringkat } \\
\hline & & & & & & 2007 & 2008 & 2009 & 2010 \\
\hline \multirow{3}{*}{1} & Permodalan & & & & & & & & \\
\hline & a. KPMM & $10.86 \%$ & $12.12 \%$ & $20.83 \%$ & $17.79 \%$ & 2 & 1 & 1 & 1 \\
\hline & b. ECR & 7.32 & 7.22 & 5.47 & 5.4 & 1 & 1 & 1 & 1 \\
\hline \multirow{3}{*}{2} & Kualitas Aset & & & & & & & & \\
\hline & a. KAP & 0.99 & 0.99 & 0.97 & 0.97 & 1 & 1 & 2 & 2 \\
\hline & b. NPF & $0.57 \%$ & $3.93 \%$ & $8.52 \%$ & $11.2 \%$ & 1 & 2 & 4 & 4 \\
\hline \multirow{5}{*}{3} & Rentabilitas & & & & & & & & \\
\hline & a. NOM & $-0.16 \%$ & $-0.36 \%$ & $-0.29 \%$ & $-0.2 \%$ & 5 & 5 & 5 & 5 \\
\hline & b. ROA & $3.14 \%$ & $0.6 \%$ & $2.13 \%$ & $1.82 \%$ & 1 & 3 & 1 & 1 \\
\hline & c. REO & $69.08 \%$ & $93.58 \%$ & $91.21 \%$ & $92.48 \%$ & 1 & 5 & 5 & 5 \\
\hline & d. ROE & $26.39 \%$ & $4.95 \%$ & $19.06 \%$ & $16.34 \%$ & 1 & 4 & 2 & 2 \\
\hline \multirow{3}{*}{4} & Likuiditas & & & & & & & & \\
\hline & a. STM & $0 \%$ & $0 \%$ & $0 \%$ & $0 \%$ & 5 & 5 & 5 & 5 \\
\hline & b. STMP & $36.64 \%$ & $35.83 \%$ & $14.91 \%$ & $11.87 \%$ & 3 & 3 & 5 & 5 \\
\hline
\end{tabular}

Sumber: Diolah dari laporan keuangan Bank Mega Syariah

Hasil penelitian di atas menggambarkan kondisi kesehatan Bank Mega Syariah yang jika dilihat secara keseluruhan cukup baik. Akan tetapi, jika dilihat per masingmasing rasio, akan terlihat kondisi yang berbeda. Salah satu yang menjadi pusat 
perhatian sekaligus mencengangkan adalah fakta bahwa bank ini memiliki kualitas likuiditas yang sangat buruk. Hal ini tercermin dari nilai rasio STM sebesar 0\% dan itu terjadi secara kontinu selama empat tahun. Kabar baiknya adalah rasio STMP yang setidaknya masih memiliki kemampuan dalam memenuhi kewajiban jangka pendek bank terhadap pihak-pihak lain, meskipun nilainya kian menurun di setiap tahun. Hal ini jelas menjadi pekerjaan rumah bagi Bank Mega Syariah untuk terus meningkatkan kinerja perusahaan.

\section{Hasil Perhitungan MDA}

Berikut ini disajikan tabel hasil perhitungan gejala financial distress dengan menggunakan metode Multiple Discriminant Analysis MDA Altman Z-Score.

a. Bank Muamalat Indonesia (BMI)

Tabel 4: Hasil Perhitungan MDA Bank Muamlat Indonesia (BMI) Tahun 2007-2010

\begin{tabular}{|c|c|c|c|c|c|c|}
\hline \multirow{2}{*}{ Tahun } & \multicolumn{5}{|c|}{ Variabel } & \\
\hline & $\mathrm{X}_{1}$ & $\mathrm{X}_{2}$ & $\mathrm{X}_{3}$ & $\mathrm{X}_{4}$ & $\mathrm{X}_{5}$ & \\
\hline 2007 & -0.345 & 0.021 & 0.02 & 0.25 & 0.121 & \\
\hline 2008 & -0.345 & 0.027 & 0.024 & 0.29 & 0.117 & \\
\hline 2009 & -0.444 & 0.017 & 0.004 & 0.37 & 0.109 & \\
\hline 2010 & -0.518 & 0.021 & 0.011 & 0.32 & 0.088 & \\
\hline Koefisien & 0.717 & 0.847 & 3.107 & 0.42 & 0.998 & $\mathrm{Z}$ \\
\hline 2007 & -0.24737 & 0.017787 & 0.06214 & 0.105 & 0.120758 & 0.05832 \\
\hline 2008 & -0.24737 & 0.022869 & 0.074568 & 0.1218 & 0.116766 & 0.088638 \\
\hline 2009 & -0.31835 & 0.014399 & 0.012428 & 0.1554 & 0.108782 & -0.02734 \\
\hline 2010 & -0.37141 & 0.017787 & 0.034177 & 0.1344 & 0.087824 & -0.09722 \\
\hline
\end{tabular}

Sumber: Diolah dari laporan keuangan Bank Muamalat Indonesia

Berdasarkan hasil perhitungan dengan menggunakan metode MDA untuk mengetahui gejala financial distress pada Bank Muamalat Indonesia, nilai ZScore bank berada di bawah 1.81. Ini berarti, Bank Muamalat Indonesia mengalami kesulitan keuangan dan berisiko tinggi yang mengarah pada kebangkrutan. Nilai $\mathrm{Z}$ yang rendah ini salah satunya disebabkan oleh nilai variabel $\mathrm{X}_{1}$ yang kecil. Nilai $\mathrm{X}_{1}$ yang mencapai angka minus dikarenakan jumlah kewajiban lancar yang lebih besar dibanding jumlah aktiva lancar. 
b. Bank Syariah Mandiri (BSM)

Tabel 5 : Hasil Perhitungan MDA Bank Syariah Mandiri (BSM)

Tahun 2007-2010

\begin{tabular}{ccccccc}
\hline \multirow{2}{*}{ Tahun } & \multicolumn{5}{c}{ Variabel } & \\
\cline { 2 - 5 } & $\mathrm{X}_{1}$ & $\mathrm{X}_{2}$ & $\mathrm{X}_{3}$ & $\mathrm{X}_{4}$ & $\mathrm{X}_{5}$ & \\
\cline { 1 - 5 } 2007 & -0.289 & 0.035 & 0.013 & 0.13 & 0.109 & \\
\cline { 1 - 5 } 2008 & -0.31 & 0.038 & 0.017 & 0.2 & 0.119 & \\
\hline 2009 & -0.389 & 0.043 & 0.02 & 0.22 & 0.11 & \\
\hline 2010 & -0.416 & 0.042 & 0.018 & 0.14 & 0.103 & \\
\hline Koefisien & 0.717 & 0.847 & 3.107 & 0.42 & 0.998 & $\mathrm{Z}$ \\
\hline 2007 & -0.20721 & 0.029645 & 0.040391 & 0.0546 & 0.108782 & 0.026205 \\
\hline 2008 & -0.22227 & 0.032186 & 0.052819 & 0.084 & 0.118762 & 0.065497 \\
\hline 2009 & -0.27891 & 0.036421 & 0.06214 & 0.0924 & 0.10978 & 0.021828 \\
\hline 2010 & -0.29827 & 0.035574 & 0.055926 & 0.0588 & 0.102794 & -0.04518 \\
\hline
\end{tabular}

Sumber: Diolah dari laporan keuangan Bank Syariah Mandiri

Hasil penelitian terkait gejala financial distress pada Bank Syariah Mandiri memberikan hasil yang senada dengan bank sebelumnya. Bank Syariah Mandiri yang notabene merupakan bank syariah terbesar di Indonesia, juga mengalami kesulitan keuangan bahkan dapat dikatakan bank ini bangkrut lantaran nilai Z-Score yang jauh dari standar minimum. Faktor utama yang menjadi pemicu kondisi ini tak lain adalah nilai $\mathrm{X}_{1}$ yang sangat kecil hingga mencapai angka minus.

c. Bank Mega Syariah (BMS)

Tabel 6: Hasil Perhitungan MDA Bank Mega Syariah (BMS)

Tahun 2007-2010

\begin{tabular}{ccccccc}
\hline \multirow{2}{*}{ Tahun } & \multicolumn{7}{c}{ Variabel } \\
\cline { 2 - 7 } & $\mathrm{X}_{1}$ & $\mathrm{X}_{2}$ & $\mathrm{X}_{3}$ & $\mathrm{X}_{4}$ & $\mathrm{X}_{5}$ & \\
\hline 2007 & -0.761 & 0.036 & 0.05 & 0.22 & 0.153 & \\
\hline 2008 & -0.538 & 0.035 & 0.008 & 0.18 & 0.119 & \\
\hline 2009 & -0.484 & 0.014 & 0.019 & 0.23 & 0.209 & \\
\hline 2010 & -0.524 & 0.021 & 0.013 & 0.18 & 0.177 & \\
\hline Koefisien & 0.717 & 0.847 & 3.107 & 0.42 & 0.998 & $\mathrm{Z}$ \\
\hline 2007 & -0.54564 & 0.030492 & 0.15535 & 0.0924 & 0.152694 & -0.1147 \\
\hline 2008 & -0.38575 & 0.029645 & 0.024856 & 0.0756 & 0.118762 & -0.13688 \\
\hline
\end{tabular}




\begin{tabular}{lllllll}
\hline 2009 & -0.34703 & 0.011858 & 0.059033 & 0.0966 & 0.208582 & 0.029045 \\
\hline 2010 & -0.37571 & 0.017787 & 0.040391 & 0.0756 & 0.176646 & -0.06528 \\
\hline
\end{tabular}

Sumber: Diolah dari laporan keuangan Bank Mega Syariah

Tabel hasil perhitungan gejala financial distress yang mengarah pada kebangkrutan dengan menggunakan metode MDA Altman Z-Score pada Bank Mega Syariah, menunjukan hasil yang sama dengan bank-bank sebelumnya yang menyatakan bahwa bank ini mengalami kesulitan keuangan. Tidak jauh berbeda dengan kedua bank sebelumnya, nilai $X_{1}$ yang berada di bawah angka 0 bahkan mencapai angka minus, ditambah nilai $X_{2}$ yang kian menurun menjadi penyebab nilai Z-Score yang dihasilkan sangat kecil dan jauh dari angka minimal yang telah ditetapkan agar terbebas dari kebangkrutan.

\section{Predikat Kesehatan Bank}

a. Faktor Capital, Asset,Earning dan Liquidity

Tabel 7: Matriks Predikat Kesehatan BMI, BSM dan BMS

Tahun 2007-2010

\begin{tabular}{ccccccc}
\hline \multirow{2}{*}{ Tahun } & \multicolumn{6}{c}{ Capital, Asset, Earning dan Liquidity } \\
\cline { 2 - 7 } & \multicolumn{2}{c}{ BMI } & \multicolumn{2}{c}{ BSM } & \multicolumn{2}{c}{ BMS } \\
\cline { 2 - 7 } & Peringkat & Predikat & Peringkat & Predikat & Peringkat & Predikat \\
\hline 2007 & 2 & Sehat & 3 & Cukup Sehat & 1 & Sangat Sehat \\
\hline 2008 & 2 & Sehat & 3 & Cukup Sehat & 2 & Sehat \\
\hline 2009 & 3 & Cukup Sehat & 3 & Cukup Sehat & 3 & Cukup Sehat \\
\hline 2010 & 2 & Sehat & 3 & Cukup Sehat & 3 & Cukup Sehat \\
\hline
\end{tabular}

Sumber: Diolah dari laporan keuangan BMI, BSM dan BMS.

Setelah pada tabel-tabel sebelumnya ditampilkan dan dinarasikan mengenai peringkat rasio dari setiap komponen di tiga bank syariah yakni BMI, BSM dan BMS, maka tabel 4.7 ini menggambarkan predikat kesehatan bank secara keseluruhan. Dari data di atas, diketahui BMI merupakan bank dengan kondisi kesehatan yang paling baik di antara dua bank lain. Sementara BSM selama periode 2007-2010 konsisten berada di peringkat 3 dengan predikat "cukup sehat". Sedangkan tingkat kesehatan BMS kian mengalami penurunan hingga di tahun 2009-2010 BMS harus puas menyandang predikat sebagai bank "cukup sehat". 
b. Metode MDA

Tabel 8: Matriks Predikat Z-Score BMI, BSM dan BMS

Tahun 2007-2010

\begin{tabular}{ccccccc}
\hline \multirow{2}{*}{ Tahun } & \multicolumn{6}{c}{ Bultiple Discriminant Analysis } \\
\cline { 2 - 7 } & Nilai Z & Predikat & Nilai Z & Predikat & Nilai Z & Predikat \\
\cline { 2 - 7 } & 0.05832 & Bangkrut & 0.02621 & Bangkrut & -0.1147 & Bangkrut \\
\hline 2007 & 0.088638 & Bangkrut & 0.0655 & Bangkrut & -0.13688 & Bangkrut \\
\hline 2008 & -0.02734 & Bangkrut & 0.02183 & Bangkrut & 0.029045 & Bangkrut \\
\hline 2009 & -0.09722 & Bangkrut & -0.0452 & Bangkrut & -0.06528 & Bangkrut \\
\hline 2010 & & & & & & \\
\hline
\end{tabular}

Sumber: Diolah dari laporan keuangan BMI, BSM dan BMS.

Dari tabel di atas dapat disimpulkan bahwa semua bank syariah yang menjadi objek penelitian ini masuk dalam kategori "bangkrut". Sebagaimana telah dijelaskan sebelumnya, nilai $\mathrm{X}_{1}$ yang berada di bawah angka 0 dan minus ditambah nilai koefisien pengali rasio $\mathrm{X}_{1}$ (net working capital to total assets) yang cukup besar menjadi faktor utama nilai $\mathrm{Z}$ sangat rendah. Berdasarkan data di atas pula, dapat terlihat bahwa Bank Mega Syariah merupakan bank yang memiliki potensi paling tinggi terhadap eksistensi gejala financial distress yang mengarah pada kebangkrutan. meskipun demikian, seluruh bank harus terus meningkatkan kinerja dan melakukan evaluasi agar terhindar dari kondisi financial distress yang mengarah pada kebangkrutan.

\section{Interpretasi dan Analisis}

Hasil perhitungan dan penilaian tingkat kesehatan bank syariah menggunakan faktor capital, assets, earning dan liquidity menunjukan ketiga bank syariah yang menjadi objek penelitian tergolong sehat. Kecuali Bank Syariah Mandiri yang selama empat tahun konsisten berada dalam kategori cukup sehat. Sementara hasil perhitungan dengan menggunakan metode MDA terhadap tiga sampel bank syariah memberikan hasil bahwa seluruh bank tergolong bangkrut di setiap tahun nya yaitu, 2007-2010. Oleh karena itu, dapat dikatakan bahwa terdapat perbedaan hasil penilaian dari kedua metode tersebut.

Walaupun metode Multiple Discriminant Analysis (MDA) yang dipelopori oleh Edward I. Altman merupakan metode yang diperuntukan untuk perusahaan manufaktur, namun seiring perjalanan waktu metode ini banyak digunakan oleh 
peneliti untuk menilai gejala financial distress di bank. Akan tetapi, penerapan metode ini ternyata tidak applicable jika dilakukan pada perbankan. Hal ini dikarenakan karakteristik perbankan sebagai financial intermediatory jauh berbeda dengan karakteristik perusahaan-perusahaan lain. Dengan ada nya fungsi tersebut memberikan implikasi bahwa bank memiliki current assets (aktiva lancar) yang lebih kecil dibandingkan current liabilities (kewajiban lancar). Aktiva lancar yang kecil tidak akan cukup untuk menutupi kewajiban lancar. ${ }^{4}$ Hal ini sangat berpengaruh terhadap variabel $\mathrm{X}_{1}$ yaitu, net working capital to total assets yang bernilai negatif pada penelitian ini.

Penelitian yang dilakukan oleh Endri pada tahun 2009 terhadap tiga bank umum syariah yaitu, Bank Muamalat Indonesia, Bank Syariah Mandiri dan Bank Mega Syariah selama tiga tahun (2005-2007) juga menunjukan nilai $\mathrm{Z}$ yang negatif atau dibawah standar minimum dan tergolong bangkrut. Hasil yang sama juga terjadi pada penelitian Rahmat yang menganalisa kemungkinan kesulitan dan kebangkrutan pada perbankan Indonesia pasca kebijakan Bank Indonesia pada tanggal 13 Maret 1999 terhadap 18 bank go-public. Hasil penelitian mengatakan bahwa, model Z-Score tidak dapat diterapkan pada dunia perbankan Indonesia, karena menghasilkan hal yang bertolak belakang terutama untuk bank-bank yang dapat beroperasi tanpa replikasi. ${ }^{5}$

Berdasarkan hasil penilaian terkait eksistensi gejala financial distress yang mengarah pada kebangkrutan menggunakan metode Multiple Discriminant Analysis (MDA) Altman Z-Score, didapatkan kenyataan bahwa semua bank syariah yang menjadi objek penelitian masuk dalam kategori bangkrut. Hasil ini diperoleh dari persamaan fungsi diskriminan Altman :

$$
\mathrm{Z}=0.717 \mathrm{X}_{1}+0.847 \mathrm{X}_{2}+3.107 \mathrm{X}_{3}+0.420 \mathrm{X}_{4}+0.998 \mathrm{X}_{5}
$$

Selanjutnya, nilai masing-masing rasio yang diwakili dengan variabel $\mathrm{X}_{1}$ sampai $\mathrm{X}_{5}$ dimasukan ke dalam persamaan tersebut untuk dikalikan dengan multiplier coefficient masing-masing dan diakumulasi sehingga mendapatkan nilai $\mathrm{Z}$. Nilai $\mathrm{Z}$ yang rendah disebabkan oleh nilai $\mathrm{X}_{1}$ yang kecil lantaran karakteristik bank sebagai lembaga depositori sehingga memiliki current liabilities yang lebih besar dibanding current assets.

Nilai $\mathrm{X}_{1}$ yang selalu digadang-gadang menjadi faktor utama nilai $\mathrm{Z}$ rendah dan memasukan semua bank ke dalam kategori bangkrut, pada akhirnya menyiratkan sebuah pertanyaan apakah variabel $\mathrm{X}_{1}$ ini benar-benar memiliki peranan yang besar

${ }^{4}$ Endri, "Prediksi Kebangkrutan Bank untuk Menghadapi dan Mengelola Perubahan Lingkungan Bisnis: Analisis Model Altman's Z-Score",Perbanas Quarterly Review, Vol. 2, (Maret, 2009), h. 41.

${ }^{5}$ Endri, "Prediksi Kebangkrutan Bank untuk Menghadapi dan Mengelola Perubahan Lingkungan Bisnis", h. 40. 
atau dominan dalam menentukan nilai Z. Untuk menjawab pertanyaan tersebut, peneliti mencoba membuat fungsi diskriminan baru dengan memasukan nilai masingmasing variabel berdasarkan hasil penelitian sebelumnya yang menggunakan formula fungsi diskriminan milik Altman. Sampel penelitian ini menggunakan objek penelitian yang terdiri atas tiga bank dengan periode empat tahun (2007-2010), sehingga jika diakumulasi jumlah sampel pada penelitian ini berjumlah 12 dengan mengabaikan unsur tahun penelitian dan nama bank pada saat pengolahan data menggunakan media SPSS. Dikarenakan pada penelitian sebelumnya semua bank masuk dalam kategori bangkrut, maka dalam membuat fungsi diskriminan baru ini penulis membuat asumsi beberapa masuk dalam kategori sehat, bangkrut dan grey area. Pada pembuatan fungsi diskriminan baru ini pula, penulis mengabaikan faktor tahun dan jenis bank agar lebih mudah pada saat proses pengolahan data.

Setelah data-data tersebut dimasukan dan diolah menggunakan bantuan SPSS, maka hasil yang diperoleh berupa fungsi diskriminan baru yaitu:

$$
\begin{aligned}
& \mathrm{D} 1=-12.575+5.489 \mathrm{X}_{1}+258.629 \mathrm{X}_{2}-163.630 \mathrm{X}_{3}+12.299 \mathrm{X}_{4}+62.244 \mathrm{X}_{5} \\
& \mathrm{D} 2=-9.288+3.388 \mathrm{X}_{1}+48.631 \mathrm{X}_{2}-5.888 \mathrm{X}_{3}+22.833 \mathrm{X}_{4}+34.973 \mathrm{X}_{5}
\end{aligned}
$$

Nilai multiplier coefficient pada persamaan di atas di dapat pada tabel canonical discriminant function coefficients seperti tergambar pada tabel di bawah ini:

Canonical Discriminant Function

Coefficients

\begin{tabular}{crr}
\hline & \multicolumn{2}{c}{ Function } \\
\cline { 2 - 3 } & \multicolumn{1}{c}{1} & \multicolumn{1}{c}{2} \\
\hline $\mathrm{x} 1$ & 5.489 & 3.388 \\
\hline $\mathrm{x} 2$ & 258.629 & 48.631 \\
\hline $\mathrm{x} 3$ & -163.630 & -5.888 \\
\hline $\mathrm{x} 4$ & 12.299 & 22.833 \\
\hline $\mathrm{x} 5$ & 62.244 & 34.973 \\
\hline (Constant) & -12.575 & -9.288 \\
\hline
\end{tabular}

Unstandardized coefficients

Dengan kedua persamaan ini, kita dapat menghitung skor diskriminan dengan fungsi 1 maupun fungsi 2 pada setiap objek. Untuk memprediksi keanggotaan setiap objek, apakah masuk dalam kategori 1, 2 atau 3, SPSS sudah memberikan hasil berupa data mengenai keanggotaan setiap objek berdasarkan peluang sebagaimana dipaparkan hasil perhitungan SPSS di bawah ini: 
Tabel 9: Hasil Analisis Berupa Predicted Group, Z-Scores dan Peluang Keanggotaan Objek

\begin{tabular}{ccccccccccccccc}
\hline $\mathrm{d}$ & $\mathrm{x} 1$ & $\mathrm{x} 2$ & $\mathrm{x} 3$ & $\mathrm{x} 4$ & $\mathrm{x} 5$ & Dis_1 & Dis1_1 & Dis2_1 & Dis1_2 & Dis2_2 & Dis3_2 \\
\hline 1 & -0.345 & 0.021 & 0.02 & 0.25 & 0.121 & 1 & -1.70371 & 0.3865 & 0.96212 & 0.00145 & 0.03643 \\
\hline 3 & -0.345 & 0.027 & 0.024 & 0.29 & 0.117 & 3 & -0.56347 & 1.42817 & 0.07652 & 0.00563 & 0.91785 \\
\hline 3 & -0.444 & 0.017 & 0.004 & 0.37 & 0.109 & 3 & 0.06537 & 2.27106 & 0.00211 & 0.00104 & 0.99685 \\
\hline 1 & -0.518 & 0.021 & 0.011 & 0.32 & 0.088 & 1 & -2.3738 & 0.29754 & 0.99653 & 0.0001 & 0.00337 \\
\hline 2 & -0.289 & 0.035 & 0.013 & 0.13 & 0.109 & 2 & 1.14709 & -1.86135 & 0.0005 & 0.99525 & 0.00425 \\
\hline 2 & -0.31 & 0.038 & 0.017 & 0.2 & 0.119 & 2 & 2.63656 & 0.13789 & 0 & 0.77852 & 0.22148 \\
\hline 3 & -0.389 & 0.043 & 0.02 & 0.22 & 0.11 & 2 & 2.69095 & 0.23761 & 0 & 0.73695 & 0.26304 \\
\hline 2 & -0.416 & 0.042 & 0.018 & 0.14 & 0.103 & 2 & 1.19175 & -1.96219 & 0.00038 & 0.99652 & 0.0031 \\
\hline 1 & -0.761 & 0.036 & 0.05 & 0.22 & 0.153 & 1 & -3.39381 & -0.03604 & 0.99994 & 0 & 0.00006 \\
\hline 2 & -0.538 & 0.035 & 0.008 & 0.18 & 0.119 & 2 & 1.83583 & -1.18419 & 0.00005 & 0.9851 & 0.01485 \\
\hline 3 & -0.484 & 0.014 & 0.019 & 0.23 & 0.209 & 3 & 1.11802 & 2.20198 & 0.00007 & 0.00316 & 0.99677 \\
\hline 1 & -0.524 & 0.021 & 0.013 & 0.18 & 0.117 & 1 & -2.65077 & -1.91698 & 0.99976 & 0.00022 & 0.00002 \\
\hline
\end{tabular}

Fakta yang diperoleh dari tabel ini adalah semua objek tepat prediksi kecuali objek nomor 6, yang semuladiasumsikan berada pada kategori 3 (grey area) ternyata masuk dalam kategori 2 (sehat). Pengklasifikasian ini diperoleh dengan melihat nilai group centroids. Nilai centroid untuk masing-masing grup dan masing-masing fungsi dijelaskan pada tabel di bawah ini:

Functions at Group Centroids

\begin{tabular}{rr}
\hline \multicolumn{2}{c}{ Function } \\
\cline { 2 - 2 } 1 & \multicolumn{1}{c}{2} \\
\hline-2.531 & -.317 \\
\hline 1.703 & -1.217 \\
\hline .828 & 1.535 \\
\hline
\end{tabular}

Lain halnya dengan model diskriminan dua grup, pada model diskriminan tiga grup atau lebih cutting score tidak lagi dapat digunakan sebagai kriteria dalam memprediksi keanggotaan setiap objek. Oleh Karena itu, program SPSS sudah melakukan prediksi serta memberikan peluang keanggotaan setiap objek. 
Salah satu cara lain yang dapat digunakan untuk melihat kenaggotaan setiap obejk adalah dengan memeriksa peta territorial. ${ }^{6}$

Peta teritorial memperlihatkan territorial setiap grup. Jika terdapat anggota grup masuk dalam teritorial grupnya, berarti keanggotaan anggota itu diperiksa secara tepat. Namun, jika awalnya anggota grup 1 tetapi masuk dalam teritori grup 2 maka keanggotaan anggota itu salah prediksi. ${ }^{7}$ Untuk melihat apakah anggota-anggota tersebut tepat prediksi atau tidak (berada di dalam atau di luar teritorial), dapat dilihat pada diagram canonical discriminant functions yang merupakan kombinasi antara territorial map dengan scattergram.

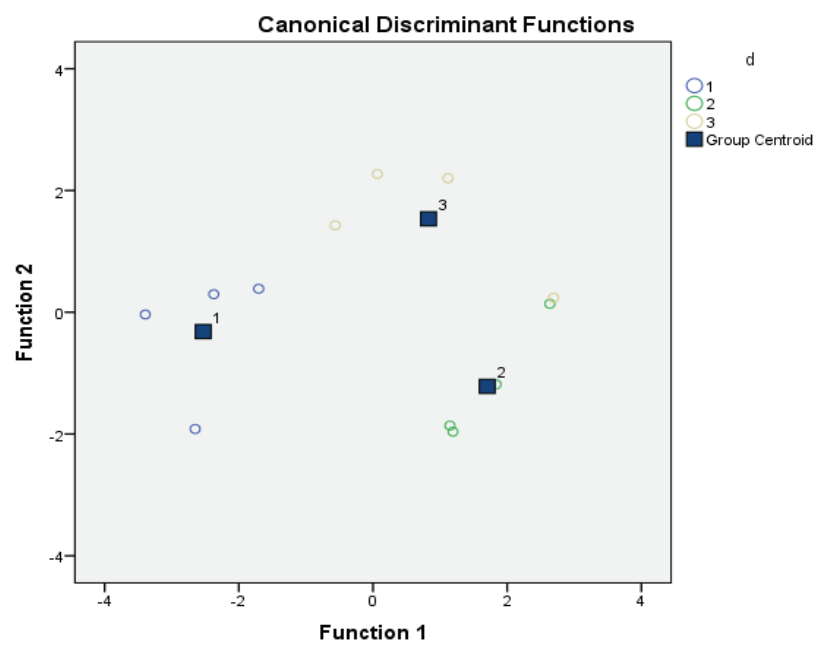

Pada diagram di atas, terlihat dari empat anggota grup 1 semuanya tepat prediksi. Begitu pun halnya dengan grup 2. Dari empat anggota grup 2 yang diprediksi semuanya tepat prediksi. Sedangkan dari empat anggota grup 3, terdapat 1 anggota yang masuk dalam grup 3 . Sehingga jumlah anggota grup yang tepat prediksi adalah 3. Selanjutnya, dari 12 total sampel terdapat 11 objek yang diprediksi secara tepat keanggotaannya. Artinya, besar hit ratio adalah 91,67\%.

Pertanyaan selanjutnya yang muncul adalah, apakah kedua fungsi diskriminan akurat dalam melakukan tugasnya. Untuk menjawab pertanyaan tersebut, kita dapat menghitung proportional chance criterion sebagaimana termaktub di bawah ini:

${ }^{6}$ Bilson Simamora, Analisis Multivariat Pemasaran, (Jakarta: PT RajaGrafindo Persada, 2005), h. $185-186$.

${ }^{7}$ Bilson Simamora, Analisis Multivariat Pemasaran, h. 186. 


$$
\begin{gathered}
\mathrm{C}_{\mathrm{PRO}}=(4 / 12)^{2}+(4 / 12)^{2}+(3 / 12)^{2} \\
=28.47 \% .
\end{gathered}
$$

Hasil perhitngan menunjukan nilai hit ratio jauh di atas CPRO, hal tersebut berarti kedua fungsi diskriminan telah melakukan tugas dengan akurat.

Hal ini tentu bertolak belakang dengan formula yang dimiliki Altman, di mana pada fungsi diskriminan milik Altman, cutting score untuk masuk ke dalam kategori financial distress yang mengarah pada kebangkrutan (grup 1) ialah jika nilai diskriminan di bawah 1.81. sementara jika nilai diskriminan berkisar antara 1.81-2.99 objek yang dalam hal ini bank syariah masuk dalam kategori grey area (grup 2) dan termasuk dalam kategori sehat (grup 3) jika nilai diskriminan di atas 2.99. Perbedan tidak hanya terletak pada cutting score yang menjadi tolak ukur atau batas minimum suatu objek masuk dalam kategori apa, melainkan juga terletak pada pemakaian grup. Jika pada metode Altman grup 1 adalah bangkrut, grup 2 masuk dalam grey area dan grup 3 adalah sehat, pada hasil penelitian ini grup 1 berada pada daerah bangkrut, grup 2 berarti bank atau objek penelitian ini masuk dalam kategori sehat dan grup 3 grey area (daerah abu-abu).

Akan tetapi, yang paling membedakan adalah hasil penelitian dengan menggunakan fungsi diskriminan yang dirancang Altman dengan fungsi diskriminan baru yang diperoleh berdasarkan hasil perhitungan menggunakan metode Altman. Hasil perhitungan mengunakan formula atau fungsi diskriminan milik Altman mengatakan semua bank syariah yang menjadi objek peneltian ini dalam kategori bangkrut. Sedangkan hasil perhitungan menggunakan fungsi diskriminan baru memberikan hasil yang variatif dan cenderung rata yaitu, empat bank tergolong bangkrut, tiga bank grey area dan lima lainnya tergolong sehat.

Jika pada penelitian-penelitian terdahulu yang pernah dilakukan, disebutkan bahwa variabel $\mathrm{X}_{1}$ (net working capital to tota lassets) merupakan faktor paling dominan yang memengaruhi nilai diskriminan dan mengakibatkan nilai D yang dihasilkan kecil. Alasan ini cukup masuk akal lantaran karakteristik bank sebagai lembaga depositori dan memiliki kewajiban lancar yang lebih besar dibanding jumlah aset yang dimilki. Pernyataan tersebut ternyata bertolak belakang dengan hasil yang diberikan SPSS. Hasil SPSS menunjukan variabel yang paling berperan adalah variabel $\mathrm{X}_{2}$ (retained earnings to total assets) dan $\mathrm{X}_{5}$ (sales to total assets). Untuk mencari tahu prediktor atau variabel independen mana yang paling berkontribusi dalam melakukan diskriminasi dapat dilihat pada tabel standardized coefficient di bawah ini: 


\author{
Standardized Canonical \\ Discriminant Function \\ Coefficients
}

\begin{tabular}{ccc}
\hline & \multicolumn{2}{c}{ Function } \\
\cline { 2 - 3 } & 1 & 2 \\
\hline $\mathrm{x} 1$ & .680 & .419 \\
\hline $\mathrm{x} 2$ & 2.304 & .433 \\
\hline $\mathrm{x} 3$ & -1.947 & -.070 \\
\hline $\mathrm{x} 4$ & .686 & 1.274 \\
\hline $\mathrm{x} 5$ & 2.012 & 1.131 \\
\hline
\end{tabular}

\section{Penutup}

Perhitungan mengenai tingkat kesehatan bank yang mengacu pada standar pengukuran kesehatan bank yang ditetapkan oleh Bank Indonesia yaitu, metode CAMELS—di mana penulis membatasinya dengan hanya menggunakan empat faktor penilaian yakni, capital (permodalan), assetquality (kualitas aset), earning (rentabilitas) dan liquidity (likuiditas)—diperoleh hasil berikut: Pertama, Bank Muamalat Indonesia masuk dalam kategori "sehat" kecuali pada tahun 2009, tingkat kesehatan bank menurun 1 tingkat ke peringkat 3 yang mengakibatkan bank masuk dalam kategori "cukup sehat".

Kedua, Bank Syariah Mandiri secara konsisten berada dalam kategori "cukup sehat". Salah satu faktor penyebab keadaan tersebut adalah jumlah kegiatan operasional bank yang tinggi, sehingga mengakibatkan inefisiensi kegiatan operasional. Hal ini sekaligus membuktikan bahwa tingkat total aset yang dimiliki oleh bank tidak mempengaruhi hasil penilaian tingkat kesehatan metode CAMELS, melainkan kinerja yang optimal dalam mengatur dan mengelola bank lah yang mempengaruhi hasil penelitian ini.

Ketiga, Bank Mega Syariah memiliki tingkat kesehatan bersifat fluktuatif dan cenderung menurun. Diawali dengan predikat bank yang "sangat sehat" di tahun 2007, kemudian menjadi bank "sehat" di tahun 2008 dan kembali turun menjadi bank yang tergolong "cukup sehat" di tahun 2009 dan 2010.

Berdasarkan hasil perhitungan yang menggunakan metode multiple discriminant analysis (MDA) untuk mengukur tingkat gejala financial distress pada bank syariah, diperoleh hasil bahwa seluruh bank syariah yang menjadi sampel kasus dalam kurun waktu empat tahun penelitian (2007-2010) berada dalam kategori "bangkrut". Hal ini disebabkan oleh Z-Score yang kurang dari 1.81. Selain itu, trend kebangkrutan pada ketiga bank syariah tersebut bersifat fluk-tuatif dan cenderung menurun. 
Hasil penelitian menggunakan formula MDA baru yang didapatkan berdasarkan hasil penelitian sebelumnya dengan menggunakan formula MDA Altman menyatakan bahwa, tidak semua objek dalam penelitian ini masuk dalam kategori bangkrut. Selain itu, 11 dari 12 sampel tepat prediksi. []

\section{Pustaka Acuan}

\section{Buku/Artikel/Makalah:}

Endri, "Prediksi Kebangkrutan Bank untuk Menghadapi dan Mengelola Perubahan Lingkungan Bisnis: Analisis Model Altman's Z-Score", Perbanas Quarterly Review, Vol. 2 No. 1, (Maret 2009).

Hasanah, Nur, "Analisa Rasio Keuangan Model Altman dan Model Springate sebagai Early Warning System (EWS) terhadap Prediksi Kondisi Bermasalah pada Bank Go Public", Fakultas Ekonomi dan Bisnis UIN Syarif Hidayatulah Jakarta, 2010.

Nur DP, Emrinaldi. "Analisis Pengaruh Praktek Tata Kelola Perusahaan (Corporate Governance) terhadap Kesulitan Keuangan (Financial Dis-tress): Suatu Kajian Empiris", Jurnal Bisnis dan Akuntansi. Vol. 9, (April, 2007).

Permana, Agung Gemah, "Penerapan Analisis Diskriminan Altman sebagai Alat Untuk Memprediksi Potensi Kebangkrutan pada Perusahaan Manufaktur yang Go Public di BEI," Fakultas Ekonomi dan Bisnis UIN Syarif Hidayatullah Jakarta, 2009.

Rodoni, Ahmad, dkk., "Prediksi Kondisi Financial Distress Perusahaan Go-Public dengan Menggunakan Analisis Multinomial Logit", Jurnal Etikonomi Ekonomi UIN Syarif Hidayatullah Jakarta, Vol. 7, No. 2 (Desember 2008).

Simamora, Bilson, Analisis Multivariat Pemasaran, Jakarta: PT. RajaGrafindo Persada, 2005.

Simanjuntak, Loisa Br, "Analisa Tingkat Kesehatan untuk Mengindikasi Gejala Financial Distress dengan Menggunakan Metode Multiple Discriminant Analysis (MDA)", Fakultas Ekonomi Universitas Trisakti, 2003.

Utaminingsih, Fitria, "Analisis Komparatif Kinerja Keuangan Bank Muamalat Indonesia (BMI) dan Bank Syariah Mega Indonesia (BSMI) Dengan Menggunakan Metode CAMEL," Jurnal Ekonomi dan Bisnis Dikta Ekonomi, Vol. 5, No. 3, (Desember 2008).

\section{Peraturan Peruandang-undangan:}

Peraturan Bank Indonesia No. 9/1/PBI/2007 tanggal 24 Januari 2007 tentang Penilaian Tingkat Kesehatan Bank Syariah. Diakses pada 6 Januari 2012 dari http://www.bi.go.id 
Surat Edaran Bank Indonesia No.9/24/DPbS/2007 tentang Sistem Penilaian Tingkat Keshatan Bank Syariah. Diakses pada 6 Januari 2012 dari http: //www.bi.go.id

\section{Website:}

http://www.bankmegasyariah.co.id

http://www.bmi.co.id

http://www.bsm.co.id 